REVIEW ARTICLE

\title{
Aldosterone and the mineralocorticoid receptor in insulin resistance and diabetes
}

Freddy J.K. Toloza ${ }^{1}$ y Carlos 0. Mendivil ${ }^{1,2 *}$

${ }^{1}$ Diabetes, Lipids and Metabolism Laboratory, School of Medicine, Universidad de los Andes; ${ }^{2}$ Section of Endocrinology, Fundación Santa Fe de Bogotá. Bogotá, Colombia

\section{ABSTRACT}

Aldosterone is a key regulator of water and electrolyte metabolism, but recent evidence from multiple lines of research also identifies it as a major player in other chronic disorders, particularly diabetes and the metabolic syndrome. In this review, we summarize relevant aspects of aldosterone production, secretion, action, the way aldosterone and the mineralocorticoid receptor may impact energy metabolism, and useful take-home messages concerning mineralocorticoid antagonism in patients with type 2 diabetes mellitus. (Rev ALAD. 2017;7:203-11)

Corresponding author: Carlos O. Mendivil,

cmendivi@uniandes.edu.co/carlosolimpo@gmail.com

Key words: Aldosterone. Electrolyte metabolism. Diabetes. Metabolic syndrome.

\section{RESUMEN}

La aldosterona es un regulador clave de metabolismo del agua y los electrólitos, pero la evidencia reciente de múltiples líneas de investigación también la identifica como un actor principal en otros trastornos crónicos, en particular en la diabetes y el síndrome metabólico. En esta revisión se resumen los aspectos relevantes de la producción de aldosterona, así como su secreción, su acción y la forma en que la aldosterona y el receptor mineralocorticoide pueden afectar al meta bolismo energético, además de aportar información útil sobre el antagonismo mineralocorticoide en pacientes con diabetes mellitus de tipo 2.

Palabras clave: Aldosterona. Metabolismo de los electrólitos. Diabetes. Síndrome Metabólico. 


\section{INTRODUCTION}

The understanding of aldosterone has evolved a great deal since its discovery and crystallization in $1953^{1}$ and the first description of hyperaldosteronism as a cause of hypertension and hypokalemia in $1955^{2}$. Initially recognized as a hormone purely concerned with water and electrolyte metabolism (hence its original name electrocortin), aldosterone and the mineralocorticoid receptor (MCR) are now known to be major players in the pathogenesis of multiple disorders, including type 2 diabetes mellitus (T2DM) and insulin resistance 3 .

\section{ALDOSTERONE AND THE MCR}

Aldosterone is produced in the zona glomerulosa, the outermost cell layer of the adrenal cortex. Being a steroid hormone, aldosterone is not stored but produced "on demand" under the influence of three regulators: Angiotensin II (AngII), plasma potassium, and adrenocorticotrophic hormone, from the most to the least potent ${ }^{4}$. Once in circulation, $50-70 \%$ of plasma aldosterone circulates bound to albumin or corticosteroid-binding globulin. After only 15-20 min, aldosterone is inactivated through conversion to tetrahydroaldosterone in the liver ${ }^{5}$. The best-characterized effects of aldosterone in epithelia are: (i) To promote sodium and water transport from the luminal to the basal side, (ii) to promote movement of potassium from the basal to the luminal side, and (iii) to promote the movement of hydrogen ions from the basal to the luminal side ${ }^{6}$. Consequently, clinically overt aldosterone excess is characterized by arterial hypertension (secondary to sodium and water retention), hypokalemia, and alkalosis.

\section{Regulation of aldosterone secretion}

As mentioned above, aldosterone production and secretion are regulated to a large extent by the renin-Ang system and by plasma potassium. When the juxtaglomerular apparatus of nephrons detects a reduction in perfusion pressure or the sodium content of the tubular filtrate, it secretes the protease renin. Renin cleaves liver-produced angiotensinogen to Angl (a decapeptide), which is further processed to Angll (an octapeptide) by angiote sin-converting enzyme ( $A C E)$ in the lung and othẹr organs. Angll stimulates aldosterone secretion by the adrenal, and aldosterone, in turn, causes watê̆ and sodium retention in the kidney. The ensuing increase in plasma volume and restoration of renal perfusion increase renal sodium filtration, thựs closing a feedback loop?.

An approach to the regulation of aldosterone by Afgll and $\mathrm{K}^{+}$implies an understanding of aldosterone biosynthesis. Aldosterone biosynthesis in the zoma glomerulosa cells starts with the import of choles. terol from the cytosol to the inner mitochondriạl membrane by steroidogenic acute regulatory prötein (StAR). There the side-chain cleaving enzyme (desmolase) encoded by CYP11A1 cuts between car bons 20 and 22 to generate pregnenolone. Pregnen olone undergoes dehydrogenation by microsomă 3-beta-hydroxysteroid dehydrogenase, yielding progesterone. Progesterone is then subjected to a se ries of consecutive hydroxylations by enzymes of the cytochrome P450 family: First, in carbon 21 to pröduce 11-deoxycorticosterone, and then, in carbons 11 and 18 (twice) by aldosterone synthase (CYP11B2) (Fig. 1) ${ }^{8}$. Finally, a water molecule is spontaneousty extruded from the two hydroxyl groups at carbon 18 , giving rise to aldosterone. The two rate-limiting enzymes for aldosterone production are StAR and aldosterone synthase. Transcription of the genes för both enzymes is stimulated by increases in cytosolic $\mathrm{Ca}^{++}$in glomerulosa cells. Angll binding to the Type I Angll receptor activates the phospholipase $\mathrm{C}$ - protein kinase $C$ signaling pathway, leading to $\mathrm{Ca}^{++}$release from intracellular stores, increase in StAR and aldosterone synthase transcription and eventually 


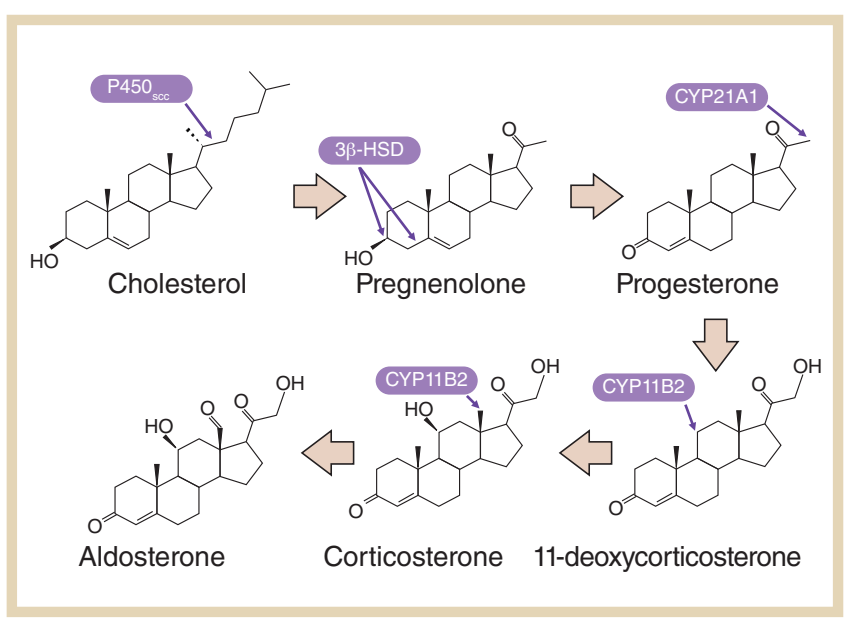

FigURE 1. Summary of the biosynthetic pathway for aldosterone. P450scc: Desmolase, 3beta-HSD: 3-beta-hydroxysteroid dehydrogenase, CYP21A1: 21-hydroxylase, CYP11B2: Aldosterone synthase.

aldosterone secretion. In the case of $\mathrm{K}^{+}$, glomerulosa cells are characterized by a high $\mathrm{K}^{+}$conductance, so even minuscule changes in plasma $\mathrm{K}^{+}$concentration depolarize their plasma membrane and cause opening of voltage-dependent $\mathrm{Ca}^{++}$channels, $\mathrm{Ca}^{++}$entry, and aldosterone secretion ${ }^{4}$.

\section{Aldosterone action and the MCR}

The very existence of an MCR was for a long time controversial until its cloning and characterization in $1987^{9}$, almost 35 years after the discovery of aldosterone. The MCR belongs to the $3 \mathrm{C}$ family of nuclear receptors, which also includes the cortisol, progesterone, and androgen receptors. In reality, the so-called MCR has an equal affinity for aldosterone and cortisol and binds many other 3-ketosteroids as well ${ }^{10}$. This has important implications. Given that cortisol concentrations in plasma are more than 100fold higher than those of aldosterone, the specificity of aldosterone binding to the MCR in the kidney is achieved through the action of 11-beta-hydroxysteroid dehydrogenase Type II (11-beta-HSD-II), an enzyme that converts cortisol to inactive cortisone. Expression of 11-beta-HSD-II outside the kidney is virtually null. Hence, aldosterone is the primary ligand of the MCR in the kidney, but in extrarenal tissues the MCR is activated mostly by cortisol.

When not occupied by a ligand, the MCR lies in the cytosol, bound to the chaperone HSP9o. Binding òf aldosterone or other ligand to the MCR induces its translocation to the nucleus and conformational change to the transcriptionally active state ${ }^{11}$. MCR activation augments membrane expression of the epithelial sodium transporter epithelial sodium channels (ENaC) by an indirect mechanism. MCR activă tion strongly induces expression of the serum- and glucocorticoid-regulated kinase 1 (sgk-1). Normally, $\mathrm{ENaC}$ is degraded in the proteasome after ubiquitination by the protein Nedd4-2 $2^{12}$. Sgk-1 phosphorylates and inactivates Nedd2-4 $4^{13}$, leading to prolonged residence of $\mathrm{ENaC}$ in the apical membrane and in creased sodium transport from the tubular lumen to the cell cytoplasm. Activated MCR also increases ex pression of the gene for the $\mathrm{Na}^{+} / \mathrm{K}^{+}$ATPase, leading to sodium transport from the cytoplasm to the intercellular space, and of $\mathrm{K}^{+}$from the intercellular space to the cell cytoplasm and eventually (due to leakage) into the tubular lumen ${ }^{14}$ (Fig. 2).

Aldosterone also has many established effects bẹyond water and electrolyte transport. These "non-classic" effects of aldosterone include collăgen synthesis, secretion of growth factors, secrètion of plasminogen inhibitor activator-1 (PAi-1), and activation of proinflammatory genes ${ }^{15}$.

\section{INFLUENCE OF ALDOSTERONE/MCR ACTIVATION ON INSULIN ACTION AND GLUCOSE METABOLISM}

\section{Aldosterone, MCR, and beta-cell function}

It is well known that hyperaldosteronism-associated hypokalemia impairs insulin secretion ${ }^{16,17}$ and that this 
defect is only partially reversible after reestablishment of normal plasma $\mathrm{K}^{+18}$. Induction of hyperaldosteronism in mouse models of diabetes leads to worsening of glucose tolerance, decreased beta-cell mass, and increased oxidative stress markers ${ }^{19,20}$. Interestingly, MCR antagonism with spironolactone only partially antagonizes these effects, while diet supplementation with the antioxidant $\mathrm{N}$-acetylcysteine

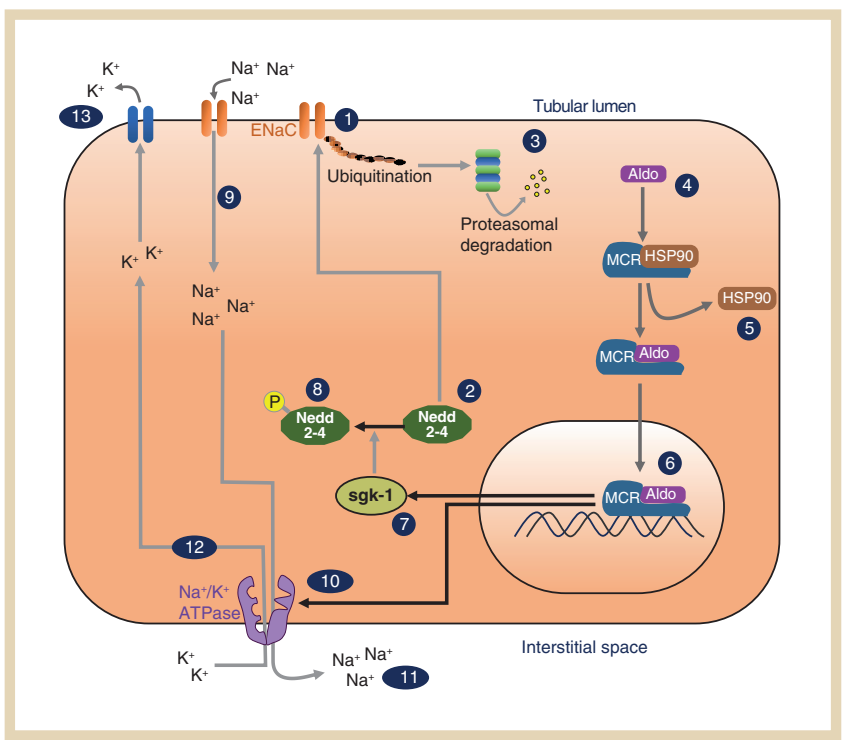

Figure 2. Cellular mechanism of aldosterone action in epithelial cells of the renal distal tubule. (1) The apical epithelial sodium channels $(\mathrm{ENaC})$ are normally ubiquitinated by (2) the enzyme Nedd2-4. This leads to their proteasomal degradation (3) and a reduction in sodium transport from the tubular lumen to the cytosol. Binding of aldosterone (4) to the mineralocorticoid receptor (MCR) induces (5) release of the chaperone HSP90, traslocation of the aldo-MCR complex to the nucleus, and (6) transactivation of target genes. One of the expressed genes is (7) serum and glucocorticoid-regulated kinase 1, a Ser/Thr kinase that (8) phosphorylates Nedd2-4, inactivating it. This causes a longer residence time of $\mathrm{ENaC}$ molecules at the apical membrane and (9) subsequent $\mathrm{Na}^{+}$entry into the cytosol. Another target gene of the MCR is that of the $\mathrm{Na}^{+} / \mathrm{K}^{+}$ATPase, whose increased expression facilitates (11) passage of intracellular sodium to the interstitial space and (12) concomitant potassium transport from the interstitium to the cytosol. As this $\mathrm{K}^{+}$accumulates, leakage channels allow their (13) escape into the tubular filtrate.
(NAC) completely abolishes them ${ }^{19,21}$. Taken together, these results suggest the existence of MCR-independent mechanisms that mediate aldosterone-induced beta-cell dysfunction, probably involving the generation of oxidative stress ${ }^{19}$.

\section{Aldosterone, MCR, and peripheral insulin action}

Activation of the MCR in blood vessels, skeletal muscle, and adipose tissue elicits relevant metabolic effects. Adequate peripheral glucose uptake is determined by tissue perfusion, glucose diffusion through cellular membranes, and patent insulin signaling pathways ${ }^{22-25}$. In the endothelium, MCR activation reduces nitric oxide production and increases reactive oxygen species (ROS) production through in duction of nicotinamide adenine dinucleotide phos phate (NADPH) oxidase. These actions initially cause endothelial dysfunction and ultimately impair insulin action at the target tissue ${ }^{26-28}$. In addition, MCR activation in vascular smooth muscle cells reduces the expression of insulin receptor substrate-1 (IRS-1) and downstream Akt signaling, directly inducing insulin resistance ${ }^{29,30}$. In the same cell type, MCR activation induces anomalous formation of insulin receptorl insulin-like growth factor-1 receptor dimers in the plasma membrane ${ }^{31,32}$, further impeding insulin sig naling. Skeletal muscle as the quantitatively dominant target of insulin action is also affected by aldö. sterone and MCR activation ${ }^{33}$. In Wistar rats, systemic administration of aldosterone reducès skeletal muscle glucose uptake, along with depleted insulin receptors and reduced expression and phos. phorylation of signaling molecules IRS-1 and Akt33,34. Likewise, when MCR were blocked in the Ren2 rat (a model of secondary hyperaldosteronism and insulin resistance) insulin sensitivity and insulin receptor signaling improved markedly, while NADPH oxidase activity and ROS production declined 35 . 
The other major target of insulin action is adipose tissue. In vitro studies have revealed a negative impact of aldosterone administration on insulin response by cultured 3T3 adipocytes, accompanied by a drop in IRS-1 and IRS-2 expression, Akt-1 phosphorylation, and 2-deoxyglucose uptake ${ }^{36,37}$. In the same cell culture model, supplementation of the medium with aldosterone greatly reduced adiponectin mRNA synthesis while enhancing PAi-1 expression in a dose-dependent fashion ${ }^{38,39}$. Both changes are known to be related with worsened adipocyte insulin sensitivity ${ }^{40,41}$. Furthermore, in vivo models have confirmed that MCR antagonism (eplerenone) improves tissue expression of the adipocyte health markers adiponectin and peroxisome-proliferator-activated receptor-gamma ${ }^{42,43}$.

\section{ASSOCIATION BETWEEN ALDOSTERONE/MCR ACTIVATION AND GLUCOSE METABOLISM IN HUMANS}

Separate studies have found cross-sectional associations between plasma concentrations of aldosterone and insulin resistance measured by the homeostasis model assessment - insulin resistance (HOMA-IR) or hyperinsulinemic-euglycemic clamp in participants with obesity 44,45 , essential hypertension $^{46-48}$, heart failure (HF) ${ }^{49,50}$, or primary hyperaldosteronism ${ }^{51-53}$. Nevertheless, only one prospective study has found high plasma aldosterone levels to be predictive of future development of insulin resistance in initially non-diabetic subjects after a 10-year follow-up ${ }^{54}$. Of note, patients with primary hyperaldosteronism who underwent adrenalectomy and were followed for 5.2 years showed a significantly lower incidence of T2DM compared to controls with essential hypertension (Hazard Ratio $[\mathrm{HR}]=0.60, P<0.01)^{55}$. Patients with primary hyperaldosteronism treated with adrenalectomy or MCR blockers and followed for 6 months demonstrated improvements in insulin resistance measured as
HOMA-IR or area under the insulin curve in an oral glucose tolerance test ${ }^{56}$. Even though these findings suggest that aldosterone blockage or inhibition could have positive repercussions in insulin sensitiv ity and prevention on T2DM, current evidence is insufficient and randomized trials will have to be undertaken to address this particular hypothesis.

\section{CLINICAL IMPLICATIONS OF MCR ACTIVATION IN PATIENTS WITH DIABETES, PREDIABETES, OR THE METABOLIC SYNDROME}

\section{Screen for mineralocorticoid excess in patients with T2DM}

Up to $70 \%$ of patients with T2DM are hypertensive $57-59$ and up to $15 \%$ of patients with hypertension have some degree of hyperaldosteronism ${ }^{60-62}$. However, the possibility of primary aldosteronism in patients with T2DM and hypertension is often overlooked, in part because hypertension is often attributed to ot er risk factors commonly encountered in T2DM pătients. The prevalence of primary hyperaldosteronism in subjects with T2DM and uncontrolled ö resistant hypertension ranges from $11 \%$ to $24 \%$ in different populations ${ }^{63-65}$. This evidence highlights the relevance of screening for hyperaldosteronism in T2DM, especially when there is resistant hyperten sion, mild or overt hypokalemia or family history ö hyperaldosteronism ${ }^{66,67}$. The screening test recommended by current guidelines is the plasma aldoste rone concentration/plasma renin activity ratio ${ }^{68}$.

\section{When needed, select the best MCR antagonist for your patient with T2DM}

Since the first description of an orally bioavailable MCR antagonist (spironolactone) by Cella and 
collaborators in 1957, there have been major developments in this drug family ${ }^{69}$. Current available MCR antagonists might be roughly classified into steroidal (spironolactone, eplerenone) and non-steroidal (finerenone, esaxerenone) compounds, but so far only steroidal compounds have been approved for use in humans ${ }^{70}$. Differences between these two drug subfamilies lie in their potency and MCR selectivity70,71. Spironolactone is a potent, competitive antagonist of the MCR that also has significant antagonist activities at the androgen and progesterone receptor ${ }^{72}$. This causes undesirable side effects such as gynecomastia, sexual impotence, and menstrual irregularities in a fraction of patients ${ }^{73}$. For this reason, later generations of MCR antagonists have been aimed primarily at the improvement of MCR selectivity and the reduction of side effects. In 1989, eplerenone emerged as a more selective MCR antagonist but with a much lower potency (about 40-fold lower) and affinity for the MCR compared to spironolactone. Thus, eplerenone is a less potent yet better-tolerated alternative to spironolactone. Due to its anti-androgen effect, spironolactone treatment may slightly worsen glycemic control in patients with $\mathrm{T}_{2} \mathrm{DM}^{74}$, while eplerenone may have a mildly positive effect on glycemic control75,76. Meanwhile, finerenone is a heterobicyclic analog of naphthyridine derivatives. Finerenone is at least as potent as spironolactone but has a much better selectivity toward the MCR than eplerenone (about 500-fold greater). Evidence on the clinical benefits of finerenone in T2DM patients with various comorbidities is growing fast (please see below).

\section{MCR antagonists reduce mortality in patients with T2DM and HF}

Use of mineralocorticoid antagonists reduces mortality in patients with T2DM and HF in different clinical settings. A recent meta-analysis of four randomized clinical trials estimated the mortality impact of MCR antagonists in these patients at 22\% (95\% confidence interval [Cl]: 12-31\%) ${ }^{77}$. Khosraviani et al. ${ }^{78}$ compared the mortality impact of MCR antagonism in patients with or without T2DM. In this observational study of 3160 patients with systolic HF (left ventricle ejection fraction < 35\%) concomitantly receivinga beta-blocker plus an ACE inhibitor or angiotensin-rē ceptor blocker, 2-year all-cause mortality was rèduced by an absolute 5.2\% (relative risk [RR]: 0.70, 95\% $\mathrm{Cl}$ 0.54-0.91) among spironolactone users with T2DM. Remarkably, this effect did not exist in HF patients without T2DM (RR: 0.89, 95\% Cl: 0.67-1.19).

In the EPHESUS trial, treatment of patients with T2DM and HF with eplerenone following an acute myocardial infarction reduced the risk of cardiovascular death or cardiovascular hospitalization by $17 \% 79$. Similarly, subgroup analyses of the EMPHASIS-HF study found a $46 \%$ reduction in the primary compos. ite endpoint of hospitalization for HF or death from cardiovascular causes for patients with T2DM who received eplerenone ( $\mathrm{HR} 0.54,95 \% \mathrm{Cl}: 0.42-0.70)$ ( Supported by this evidence, the 2016 ACC/AHA/HFS $\mathrm{HF}$ guidelines update recommends the use of $M \mathrm{C}_{\mathrm{R}}$ blockers in patients with diabetes and HF with re duced ejection fraction, additional to inhibition of the renin-Ang system ${ }^{81}$.The efficacy and safety of finerenone in the context of HF was evaluated in the Mineralocorticoid Receptor antagonist Tolerability Study$\mathrm{HF}^{82}$. This study compared the use of different dosè of finerenone versus eplerenone for 90 days in pă tients with worsening HF and chronic kidney disease and/or diabetes mellitus. The primary endpoint of a $30 \%$ or greater reduction in N-terminal pro-B-type nă triuretic peptide occurred at similar rates in all study groups. However, a secondary composite outcome of death from any cause, cardiovascular hospitalization, or emergency presentation to hospital occurred at the lowest rate in the finerenone $10 \mathrm{mg}$ group (HR vs. eplerenone: 0.56; $95 \% \mathrm{Cl}: 0.35-0.90)^{82}$. 


\section{MCR antagonists may provide renal benefits in patients with T2DM}

MR blockers also have shown to improve surrogate markers of renal dysfunction in patients with $\mathrm{T}_{2} \mathrm{DM}^{83-}$ 85. In patients with diagnosed diabetic nephropathy, the addition of finerenone to an Angll-receptor blocker or ACE inhibitor resulted in improvements in the urinary albumin/creatinine ratio compared with placebo ${ }^{86}$. Likewise, a second study in Japanese patients with diabetic nephropathy found an anti-albuminuric effect of finerenone addition to inhibition of renin-Ang system, without increases in serum potassium or deterioration of glomerular filtration ${ }^{87}$.

\section{MCR antagonists are indicated, yet seldom used, in patients with T2DM and resistant hypertension}

Multiple studies have addressed the role of $M R$ antagonists in the management of hypertensive patients with $\mathrm{T}_{2} \mathrm{DM}^{88-90}$. A recent meta-analysis comprising eight randomized trials and one prospective observational study concluded that $M C R$ blockers provide a $9.4 \mathrm{mmHg}$ reduction $(95 \% \mathrm{Cl}$ : 12.9-5.9) in systolic blood pressure and a $3.8 \mathrm{mmHg}$ (95\% Cl: 5.5-2.2) reduction in diastolic blood pressure compared with placebo ${ }^{91}$. The effect was even greater in patients already receiving an ACE inhibitor or Angll receptor antagonist and was accompanied by only mild increases in plasma potassium (0.4 mEq/L, 95\% Cl: 0.3-0.5 mEq/L). Urinary albumin excretion was also systematically reduced across studies. Despite all the available evidence demonstrating morbidity and mortality advantages for selected patients treated with MCR antagonists, they are underutilized in clinical practice ${ }^{92}$. It has been estimated that only $32 \%$ of patients eligible for an MCR antagonist are actually prescribed one ${ }^{93}$.

\section{CONCLUSION}

Aldosterone and the MCR are relevant players in the pathogenesis and management of diabetes and its complications. Clinicians should bear in mind the potential advantages of blocking MCR in patients with T2DM who may benefit from such therapy.

\section{REFERENCES}

1. Simpson SA, Tait JF, Wettstein A, et al. Isolierung eines neuen kristăl lisierten hormons aus nebennieren mit besonders hoher wirksamkè auf den mineralstoffwechsel. Experientia. 1953;9:333-5.

2. Conn JW. Presidential address. I. Painting background. II. Primary aldosteronism, a new clinical syndrome. J Lab Clin Med. 1955;45:3-\$7.

3. Tomaschitz A, Ritz E, Pieske B, et al. Aldosterone and parathyroid hormone interactions as mediators of metabolic and cardiovascular disease. Metabolism. 2014;63:20-31.

4. Bollag WB. Regulation of aldosterone synthesis and secretion. Compr Physiol. 2014;4:1017-55.

5. Luetscher JA, Hancock EW, Camargo CA, Dowdy AJ, Nokes GW. Conjugation of 1, 2-3h-aldosterone in human liver and kidneys and rêa extraction of aldosterone and labeled conjugates from blood plasma. J Clin Endocrinol Metab. 1965;25:628-38.

6. Crabbé J. Stimulation of active sodium transport by the isolated toạd bladder with aldosterone in vitro. J Clin Invest. 1961;40:2103-10.

7. Okubo S, Niimura F, Nishimura $\mathrm{H}$, et al. Angiotensin-independent mechanism for aldosterone synthesis during chronic extracellular fluid volume depletion. J Clin Invest. 1997;99:855-60.

8. Vinson GP, Whitehouse BJ, Goddard C, Sibley CP. Comparative and evolutionary aspects of aldosterone secretion and zona glomerulosa function. J Endocrinol. 1979;81:5P-24.

9. Arriza JL, Weinberger C, Cerelli G, et al. Cloning of human mineralocorticoid receptor complementary DNA: structural and functional kinship with the glucocorticoid receptor. Science. 1987;237:268-75.

10. Rogerson FM, Brennan FE, Fuller PJ. Dissecting mineralocorticoidd receptor structure and function. J Steroid Biochem Mol Biol. 2003; 85:389-96.

11. Fuller PJ, Young MJ. Mechanisms of mineralocorticoid action. Hypertension. 2005;46:1227-35.

12. Debonneville C, Flores SY, Kamynina E, et al. Phosphorylation of nedd4-2 by sgk1 regulates epithelial na $(+)$ channel cell surface expression. EMBO J. 2001;20:7052-9.

13. Chen SY, Bhargava A, Mastroberardino L, et al. Epithelial sodiự channel regulated by aldosterone-induced protein Sgk. Proc Nat Acad Sci U S A. 1999;96:2514-9.

14. Béguin P, Crambert G, Guennoun S, et al. CHIF, a member of the FXÝD protein family, is a regulator of na, K-ATPase distinct from the gan̂ma-subunit. EMBO J. 2001;20:3993-4002.

15. Lösel RM, Feuring M, Falkenstein E, Wehling M. Nongenomic effects of aldosterone: Cellular aspects and clinical implications. Steroids. 2002;67:493-8.

16. Conn JW, Knopf RF, Nesbit RM. Clinical characteristics of Primary aldosteronism from an analysis of 145 cases. Am J Surg. 1964;107: 159-72.

17. Corry DB, Tuck ML. The effect of aldosterone on glucose metabolism. Curr Hypertens Rep. 2003;5:106-9. 
18. Conn JW. Hypertension, the potassium ion and impaired carbohydrate tolerance. N Engl J Med. 1965;273:1135-43.

19. Jin HM, Zhou DC, Gu HF, et al. Antioxidant N-acetylcysteine protects pancreatic $\beta$-cells against aldosterone-induced oxidative stress and apoptosis in female $\mathrm{db} / \mathrm{db}$ mice and insulin-producing MIN6 cells. Endocrinology. 2013;154:4068-77.

20. Luther JM, Luo P, Kreger MT, et al. Aldosterone decreases glucose-stimulated insulin secretion in vivo in mice and in murine islets. Diabetologia. 2011;54:2152-63.

21. Lasram MM, Dhouib IB, Annabi A, El Fazaa S, Gharbi N. A review on the possible molecular mechanism of action of $\mathrm{N}$-acetylcysteine against insulin resistance and Type-2 diabetes development. Clin Biochem. 2015;48:1200-8.

22. Barrett EJ, Eggleston EM, Inyard AC, et al. The vascular actions of insulin control its delivery to muscle and regulate the rate-limiting step in skeletal muscle insulin action. Diabetologia. 2009;52: 752-64.

23. Vincent MA, Clerk LH, Rattigan S, Clark MG, Barrett EJ. Active role for the vasculature in the delivery of insulin to skeletal muscle. Clin Exp Pharmacol Physiol. 2005;32:302-7.

24. Samuel VT, Shulman GI. Mechanisms for insulin resistance: common threads and missing links. Cell. 2012;148:852-71.

25. Luther JM. Effects of aldosterone on insulin sensitivity and secretion. Steroids. 2014;91:54-60.

26. Pruthi D, McCurley A, Aronovitz M, et al. Aldosterone promotes vascular remodeling by direct effects on smooth muscle cell mineralocorticoid receptors. Arterioscler Thromb Vasc Biol. 2014;34: 355-64.

27. Koenig JB, Jaffe IZ. Direct role for smooth muscle cell mineralocorticoid receptors in vascular remodeling: novel mechanisms and clinical implications. Curr Hypertens Rep. 2014;16:427.

28. McCurley A, McGraw A, Pruthi D, Jaffe IZ. Smooth muscle cell mineralocorticoid receptors: role in vascular function and contribution to cardiovascular disease. Pflugers Arch. 2013;465:1661-70.

29. Bender SB, McGraw AP, Jaffe IZ, Sowers JR. Mineralocorticoid receptor-mediated vascular insulin resistance: an early contributor to diabetes-related vascular disease? Diabetes. 2013;62:313-9.

30. Hitomi $\mathrm{H}$, Kiyomoto $\mathrm{H}$, Nishiyama $\mathrm{A}$, et al. Aldosterone suppresses insulin signaling via the down regulation of insulin receptor substrate-1 in vascular smooth muscle cells. Hypertension. 2007;50:750-5.

31. Cascella T, Radhakrishnan Y, Maile LA, et al. Aldosterone enhances IGF-I-mediated signaling and biological function in vascular smooth muscle cells. Endocrinology 2010;151:5851-64.

32. Sherajee SJ, Fujita Y, Rafiq K, et al. Aldosterone induces vascular insulin resistance by increasing insulin-like growth factor-1 receptor and hybrid receptor. Arterioscler Thromb Vasc Biol. 2012;32:257-63.

33. Selvaraj J, Sathish S, Mayilvanan C, Balasubramanian K. Excess aldosterone-induced changes in insulin signaling molecules and glucose oxidation in gastrocnemius muscle of adult male rat. Mol Cell Biochem. 2013;372:113-26.

34. Selvaraj J, Muthusamy T, Srinivasan C, Balasubramanian K. Impact of excess aldosterone on glucose homeostasis in adult male rat. Clin Chim Acta. 2009;407:51-7.

35. Lastra G, Whaley-Connell A, Manrique C, et al. Low-dose spironolactone reduces reactive oxygen species generation and improves insulin-stimulated glucose transport in skeletal muscle in the $\mathrm{TG}(\mathrm{m}$ Ren2)27 rat. Am J Physiol Endocrinol Metab. 2008;295:E110-6.

36. Wada T, Ohshima S, Fujisawa E, et al. Aldosterone inhibits insulin-induced glucose uptake by degradation of insulin receptor substrate (IRS) 1 and IRS2 via a reactive oxygen species-mediated pathway in 3T3-L1 adipocytes. Endocrinology. 2009;150:1662-9.

37. Eckstein SS, Weigert C, Lehmann R. Divergent roles of IRS (Insulin receptor substrate) 1 and 2 in liver and skeletal muscle. Curr Med Chem. 2017;24:1827-52.
38. Li P, Zhang XN, Pan CM, et al. Aldosterone perturbs adiponectin and $\mathrm{PAl}-1$ expression and secretion in 3T3-L1 adipocytes. Horm Metab Res. 2011;43:464-9.

39. Vecchiola A, Lagos CF, Carvajal CA, Baudrand R, Fardella CE. Aldosterone production and signaling dysregulation in obesity. Curr Hypertens Rep. 2016;18:20.

40. Kadowaki T, Yamauchi T, Kubota N, et al. Adiponectin and adiponectin receptors in insulin resistance, diabetes, and the metabolic syndrome. J Clin Invest. 2006;116:1784-92.

41. Alessi MC, Juhan-Vague I. PAl-1 and the metabolic syndrome: links, causes, and consequences. Arterioscler Thromb Vasc Biol. 2006;26: 2200-7.

42. Hirata A, Maeda N, Hiuge A, et al. Blockade of mineralocorticoid receptor reverses adipocyte dysfunction and insulin resistance in obese mice. Cardiovasc Res. 2009;84:164-72.

43. Guo C, Ricchiuti V, Lian BQ, et al. Mineralocorticoid receptor blockade reverses obesity-related changes in expression of adiponectin, péroxisome proliferator-activated receptor-gamma, and proinflammato ry adipokines. Circulation. 2008;117:2253-61.

44. Goodfriend TL, Egan BM, Kelley DE. Plasma aldosterone, plasma lipoproteins, obesity and insulin resistance in humans. Prostaglandins Leukot Essent Fatty Acids. 1999;60:401-5.

45. Goodfriend TL, Kelley DE, Goodpaster BH, Winters SJ. Visceral obeși ty and insulin resistance are associated with plasma aldosterone levels in women. Obes Res. 1999;7:355-62.

46. Colussi G, Catena C, Lapenna R, et al. Insulin resistance and hyperin sulinemia are related to plasma aldosterone levels in hypertensive patients. Diabetes Care 2007;30:2349-54.

47. Haenni A, Reneland R, Lind L, Lithell H. Serum aldosterone change during hyperinsulinemia are correlated to body mass index and insulin sensitivity in patients with essential hypertension. J Hypertens. 2001;19:107-12.

48. Kidambi S, Kotchen JM, Krishnaswami S, Grim CE, Kotchen TA. Hypër tension, insulin resistance, and aldosterone: sex-specific relation ships. J Clin Hypertens (Greenwich). 2009;11:130-7.

49. Freel EM, Tsorlalis IK, Lewsey JD, et al. Aldosterone status associated with insulin resistance in patients with heart failure - Data from the ALOFT study. Heart. 2009;95:1920-4.

50. Suskin N, McKelvie RS, Burns RJ, et al. Glucose and insulin abnormälities relate to functional capacity in patients with congestive hear failure. Eur Heart J. 2000;21:1368-75.

51. Widimský J Jr, Sindelka G, Haas T, et al. Impaired insulin action in primary hyperaldosteronism. Physiol Res. 2000;49:241-4.

52. Giacchetti G, Ronconi V, Turchi F, et al. Aldosterone as a key mediato of the cardiometabolic syndrome in primary aldosteronism: an observational study. J Hypertens. 2007;25:177-86.

53. Shimamoto K, Shiiki M, Ise T, et al. Does insulin resistance participate in an impaired glucose tolerance in primary aldosteronism? J Hưm Hypertens. 1994;8:755-9.

54. Kumagai E, Adachi H, Jacobs DR Jr, et al. Plasma aldosterone levels and development of insulin resistance: prospective study in a gener al population. Hypertension. 2011;58:1043-8.

55. Wu VC, Chueh SJ, Chen L, et al. Risk of new-onset diabetes mellitus in primary aldosteronism: a population study over 5 years. J Hypertens. 2017;35:1698-708.

56. Catena C, Lapenna R, Baroselli S, et al. Insulin sensitivity in patients with primary aldosteronism: a follow-up study. J Clin Endocrino Metab. 2006;91:3457-63.

57. Klein R, Klein BE, Lee KE, Cruickshanks KJ, Moss SE. The incidence of hypertension in insulin-dependent diabetes. Arch Intern Med. 1996;156:622-7.

58. Campbell NR, Gilbert RE, Leiter LA, et al. Hypertension in people with Type 2 diabetes: update on pharmacologic management. Can Fam Physician. 2011;57:997-1002. 
59. Lago RM, Singh PP, Nesto RW. Diabetes and hypertension. Nat Clin Pract Endocrinol Metab. 2007;3:667.

60. Gordon RD, Ziesak MD, Tunny TJ, Stowasser M, Klemm SA. Evidence that primary aldosteronism may not be uncommon: $12 \%$ incidence among antihypertensive drug trial volunteers. Clin Exp Pharmacol Physiol. 1993;20:296-8.

61. Rossi GP, Bernini G, Caliumi C, et al. A prospective study of the prevalence of primary aldosteronism in 1,125 hypertensive patients. J Am Coll Cardiol. 2006;48:2293-300.

62. Omura M, Saito J, Yamaguchi K, Kakuta Y, Nishikawa T. Prospective study on the prevalence of secondary hypertension among hypertensive patients visiting a general outpatient clinic in japan. Hypertens Res. 2004;27:193-202.

63. Umpierrez GE, Cantey P, Smiley D, et al. Primary aldosteronism in diabetic subjects with resistant hypertension. Diabetes Care. 2007; 30:1699-703.

64. Mukherjee JJ, Khoo CM, Thai AC, et al. Type 2 diabetic patients with resistant hypertension should be screened for primary aldosteronism. Diab Vasc Dis Res. 2010;7:6-13.

65. Murase K, Nagaishi R, Takenoshita H, et al. Prevalence and clinical characteristics of primary aldosteronism in Japanese patients with Type 2 diabetes mellitus and hypertension. Endocr J. 2013;60: $967-76$.

66. Sabbadin C, Fallo F. Hyperaldosteronism: screening and diagnostic tests. High Blood Press Cardiovasc Prev. 2016;23:69-72.

67. Burrello J, Monticone S, Buffolo F, et al. Issues in the diagnosis and treatment of primary aldosteronism. High Blood Press Cardiovasc Prev. 2016;23:73-82.

68. Funder JW, Carey RM, Mantero F, et al. The management of primary aldosteronism: case detection, diagnosis, and treatment: an endocrine society clinical practice guideline. J Clin Endocrinol Metab. 2016;101:1889-916.

69. Kagawa CM, Cella JA, van Arman CG. Action of new steroids in blocking effects of aldosterone and desoxycorticosterone on salt. Science. 1957;126:1015-6.

70. Kolkhof P, Bärfacker L. 30 years of the mineralocorticoid receptor: mineralocorticoid receptor antagonists: 60 years of research and development. J Endocrinol. 2017;234:T125-40.

71. Kolkhof P, Borden SA. Molecular pharmacology of the mineralocorticoid receptor: prospects for novel therapeutics. Mol Cell Endocrinol. 2012;350:310-7.

72. Garthwaite SM, MCMahon EG. The evolution of aldosterone antagonists. Mol Cell Endocrinol. 2004;217:27-31.

73. Corvol P, Michaud A, Menard J, Freifeld M, Mahoudeau J. Antiandrogenic effect of spirolactones: mechanism of action. Endocrinology. 1975;97:52-8.

74. Swaminathan K, Davies J, George J, et al. Spironolactone for poorly controlled hypertension in Type 2 diabetes: conflicting effects on blood pressure, endothelial function, glycaemic control and hormonal profiles. Diabetologia. 2008;51:762-8.

75. Yamaji M, Tsutamoto T, Kawahara C, et al. Effect of eplerenone versus spironolactone on cortisol and hemoglobin $A_{1}(c)$ levels in patients with chronic heart failure. Am Heart J. 2010;160:915-21.

76. Zhao JV, Xu L, Lin SL, Schooling CM. Spironolactone and glucose metabolism, a systematic review and meta-analysis of randomized controlled trials. J Am Soc Hypertens. 2016;10:671-82.

77. Chen MD, Dong SS, Cai NY, et al. Efficacy and safety of mineralocorticoid receptor antagonists for patients with heart failure and diabetes mellitus: a systematic review and meta-analysis. BMC Cardiovasc Disord. 2016;16:28.
78. Khosraviani K, Eshtehardi P, Mojadidi MK, Zolty R. Mortality benefit of spironolactone in diabetic versus non-diabetic patients with congestive heart failure. J Am Coll Cardiol. 2014;63:A859.

79. O'Keefe JH, Abuissa H, Pitt B. Eplerenone improves prognosis in post myocardial infarction diabetic patients with heart failure: results from Ephesus. Diabetes Obes Metab. 2008;10:492-7.

80. Eschalier R, McMurray JJ, Swedberg K, et al. Safety and efficacy of eplerenone in patients at high risk for hyperkalemia and/or worsening renal function: analyses of the EMPHASIS-HF study subgroups (Eplerenone in mild patients hospitalization and survival study in heart failure). J Am Coll Cardiol. 2013;62:1585-93.

81. Yancy CW, Jessup M, Bozkurt B, et al. ACC/AHA/HFSA Focused Update on New Pharmacological Therapy for Heart Failure: an Update of the 2013 ACCF/AHA Guideline for the Management of Heart Failure: a Report of the American College of Cardiology/American Heart Association Task Force on Clinical Practice Guidelines and the Heart Failure Society of America. Circulation. 2016;134:e282-93.

82. Filippatos G, Anker SD, Böhm M, et al. A randomized controlled stud y of finer none vs. eplerenone in patients with worsening chronic heart failure and diabetes mellitus and/or chronic kidney disease. Eur Heart J. 2016;37:2105-14.

83. Mavrakanas TA, Gariani K, Martin PY. Mineralocorticoid receptor blockade in addition to angiotensin converting enzyme inhibitor ior angiotensin II receptor blocker treatment: An emerging paradigm in diabetic nephropathy: a systematic review. Eur J Intern Med. 2014;25:173-6.

84. Kato S, Maruyama S, Makino H, et al. Anti-albuminuric effects of spironolactone in patients with Type 2 diabetic nephropathy: a multicenter, randomized clinical trial. Clin Exp Nephrol. 2015;19:1098 106.

85. Epstein M, Williams GH, Weinberger M, et al. Selective aldosterone blockade with eplerenone reduces albuminuria in patients with Type 2 diabetes. Clin J Am Soc Nephrol 2006;1:940-51.

86. Bakris GL, Agarwal R, Chan JC, et al. Effect of finer none on albuminuria in patients with diabetic nephropathy: a randomized clinical trial. JAMA. 2015;314:884-94.

87. Katayama S, Yamada D, Nakayama M, et al. A randomized controlleèd study of finer none versus placebo in Japanese patients with Type 2 diabetes mellitus and diabetic nephropathy. J Diabetes Compličtions. 2017;31:758-65.

88. Oxlund CS, Henriksen JE, Tarnow L, et al. Low dose spironolactonge reduces blood pressure in patients with resistant hypertension and Type 2 diabetes mellitus: a double blind randomized clinical trial Hypertens. 2013;31:2094-102.

89. Nielsen SE, Schjoedt KJ, Rossing K, et al. Levels of NT-proBNP, markers of low-grade inflammation, and endothelial dysfunction during spironolactone treatment in patients with diabetic kidney disease. Renin Angiotensin Aldosterone Syst. 2013;14:161-6.

90. van den Meiracker AH, Baggen RG, Pauli S, et al. Spironolactone Type 2 diabetic nephropathy: effects on proteinuria, blood pressure and renal function. J Hypertens. 2006;24:2285-92.

91. Takahashi S, Katada J, Daida H, Kitamura F, Yokoyama K. Effects of mineralocorticoid receptor antagonists in patients with hypertension and diabetes mellitus: a systematic review and meta-analysis. J Hüm Hypertens. 2016;30:534-42.

92. Maron BA, Leopold JA. Aldosterone receptor antagonists: effective but often forgotten. Circulation. 2010;121:934-9.

93. Albert NM, Yancy CW, Liang L, Hernancez A, Fonarow G. Evolving patterns of use of aldosterone inhibition in chronic heart failure: a report from get with the guidelines-HF. Circulation. 2008;118:S-798. 